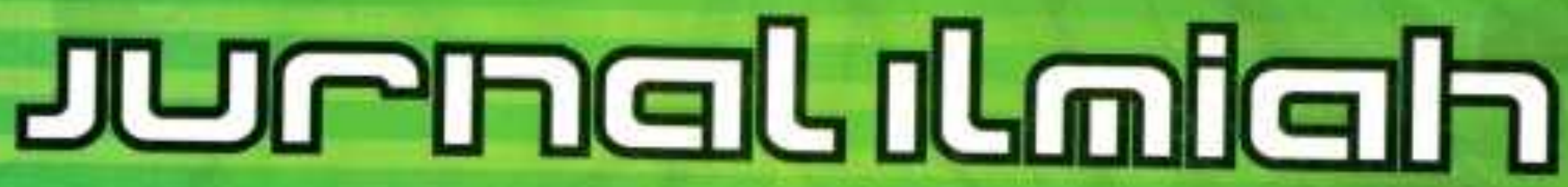

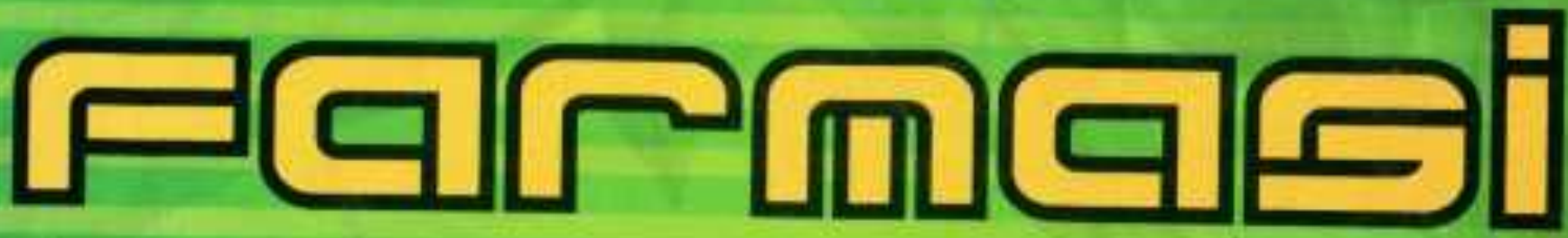 \\ (Scientific Journal of Pharmacy)
}

\section{Research}

Pengaruh Pemberian Susu Kuda Fermentasi terhadap Antibodi Imunoglobulin A (lgA) Mencit setelah Vaksinasi Hepatitis A

Rochmylstikharah, Ediatl, Rumiyat

Peningkatan Disolusi Furosemida dengan Pembentukan Kompleks Inklusi melalui Kopresipitasi Menggunakan DS Siklodekstrin

Nurul Ainah, Yandi Syukn, M. Hatta Prabowo

Isolasi dan Identifikasi Flavonoid Fraksi Air Kayu Secang (Caesalpinia sappan. L) secara Kromatografi Lapis Tipis dan SpektrofotometriUV-Vis

Losya Foumia Sari, Suparmi

Uj Efek Hepatoprotektif Infus Herba Pegagan (Centella asiatica, (L.) Urb) pada Tikus Puth Galur Wistar yang Terinduksi Parasetamol

Islamiyah Neda Rahayu, Fanida Hayati

\section{KJinika}

Uji Kepekaan Bakteri Escherichia coli Hasil Isolasi dari Urin Pasien Rumah Sakit Dr. Sardjito terhadap Antibiotik Golongan - Laktarn

Sri Hamanik, Sri Mulyaningsih, Asih Thastuti

Review

Diagnosis Dini Toksoplasmosis Kongenital dengan PCR Cairan Amnion Umatuikhoinyah

Penghambatan Quorum Sensing sebagai Alternatif Terapi Penyakit Infeksi yang Disebabkan oleh Bakteri Shofyatul Yumna Triana, Farida Juliantina, Rachmawat

Ditertitkan oleh: Jurusan Farmasi Fakultas MIPA Universitas islam Indonesia Jogiakarta 


\section{DAFTAR ISI}

Daftar isi

Pengantar Dari Dewan Editor

颟

Petunjuk Bagi Penulis

iiv

\section{Research}

Pengaruh Pemberian Susu Kuda Fermentasi terhadap Antibodi Imunoglobulin A (IgA) Mencit setelah Vaksinasi Hepatitis A

Rochmy Istikharah, Ediati, Rumiyati

Peningkatan Disolusi Furosemida dengan Pembentukan Kompleks Inklusi metalui 10 Kopresipitasi Menggunakan ß-Siklodekstrin

Nurul Ainah, Yandi Syukri, M. Hatta Prabowo

Isolasi dan Identifikasi Flavonoid Fraksi Air Kayu Secang (Caesalpinia sappan. L) secara Kromatografi Lapis Tipis dan Spektrofotometri UV.Vis

Lolyta Fournia Sari, Suparmi

Uji Efek Hepatoprotektif Infus Herba Pegagan (Centella asiatica, (L.) Urb) pada Tikus Putih Galur Wistar yang Terinduksi Parasetamol Islamiyah Neda Rahayu, Farida Hayati

Klinika

Uji Kepekaan Bakteri Escherichia cow Hasil Isolasi dari Urin Pasien Rumah Sakit Dr. Sardjito terthadap Antibiotik Golongan ft-Laktam

Sri Harnanik, Sri Mulyaningsih, Asih Triastuti

\section{Review}

Diagnosis Dini Toksopłasmosis Kongenital dengan PCR Cairan Amnion Umatul Khoiriyah Penghambatan Quorum Sensing sebagai Altematif Terapi Penyakit Infeksi yang
Disebabkan oleh Bakteri

Shofyatul Yumna Trians, Fanida Juliantina, Aachmawat 


\section{PENGANTAR DARI DEWAN EDITOR}

Puji syukur kahadirat Allah swt yang telah memberikan rahmat dan hidayah-Nya sehingga edisi ketiga Jumal Ilmiah Farmasi (JIF) Vol 3. No. 1 Th 2005 inì dapat terbit. Pada penerbitan ketiga kall ini dimuat tujuh artikei yang terdiri dari empat research, satu klinika dan dua review. Penelitian tentang Pengaruh Pemberian Susu Kuda Fermentasi terhadap Antibodi Imunoglobufin A (lgA) Mencit setelah Vaksinasi Hepatitis A oleh Rochmy Istikhatah diki: Peningkatan Disolusi Furosemida dengan Pembentukan Kompleks Inklusi meialui Kopresipitasi Menggunakan B-Siklodekstrin oleh Nurul Ainah dkk; Isolasi dan Identifikasi Flavonoid Fraksi Air Kayu Secang (Caesalpinia sappan. L) secara Kromatografi Lapis Tipis dan Spektrofotometri UV-Vis oleh Lolyta Foumia Sari dan Suparmi; serta Uji Efek Hepatoprotektif Infus Herba Pegagan (Centella asiatica, (L) Urb) pada Tikus Putih Galur Wistar yang Terinduksi Parasetamol oleh Islamiyah Neda Rahayu dan Farida Hayafi dapat disimak pada bagian Research dari jurnal ini. Sedangkan dalam Klinika disampaikan hasil penelitian Sri Hamanik dik. tentang Uji Kepekaan Bakteri Eschenichia coli Hasil Isolasi dari Urin Pasien Rumah Sakit Dr. Sardjito terhadap Antibiotik Golongan B-Laktam. Review artikel tentang Diagnosis Dini Toksoplasmosis Kongenital dengan PCR Cairan Amnion disampaikan oleh Umatul Khoiriyah dan Shofyatul Yumna Triana dkk mengulas tentang Penghambatan Quorum Sensing sebagai Alternatif Terapi Penyakit Infeksi yang Disebabkan oleh Bakteri.

Saran dan kritik dari pembaca, sangat diharapkan. Akhirnya semoga pembaca dapat mengambil ilmu dan manfaatnya. Selamat Membaca!

Jogjakarta, April 2005 


\section{PETUNJUK SINGKAT BAGI PENULIS}

1. Naskah harus berupa hasil penelitian yang belum dan tidak permah dipublikasikan dalam media cetak lain

2. Naskah dapat merupakan hasil penelitian, survey, atau telaah pustaka yang erat kaitannya dengan bidang kefarmasian, kesehatan, dan fingkingan hidup.

3. Naskah ditulis dalam bahasa Indonesia dengan intisaai dalam bahasa lnggris. Naskah berupa ketikan asli dan rekaman dalam disket.

4. Sistematika penulisan disusun dengan urutan sehagai berikut:

a. Judul diusahakan cukup informatif dan ticlak terlalu panjang

b. Nama (nama-nama) penulís (tanpa gelar) dan institusij atamat tempat bekerja ditulis lengicap dan jelas

c. Inbsari dan kata kunci (dalam bahasa Inggris). Intisan tidak lobih dan 250 kata dan kata kunci (heywords) terdifi dan 1-4 kata

d. Pendahuluan beirisi latar belakang, tujuan penelitian, masalah yang mendasari penelitian dan tinjauan teori

e. Metodologi menguraikan bahan dan alat yang digunakan dan jalanmya penelitian

f. Hasil dan pembahasan

g. Kesimpulan dan saran

h. Ucapan terima kasih (bila ada) dan;

1. Daftar pustaka

5. Cara penulisarn. Abstrak ditulis deogan jarak 1 spasi dan naskah 2 spasi, panjang naskah 10 sampai 15 halaman, dengan format atas dan kiri berjarak $4 \mathrm{~cm}$, kanan dan bawah $3 \mathrm{~cm}$ dan tepi kertas ukuran kuarto.

6. Tabel harus utuh, dan jelas lerbaca dengan judul tabel di bagian atas dengan nomor unut angka romaw. Gambar serti grafik dicantumkan pada kertas tersendin (tidak ditempelkan pada naskah), di belakangnya ditulis dengan pensil judul nuskah dan penuli5, besarnya antara $1 / 4$ sampai 1 hakaman dengan keterangan gambarkgrafik di bagian bawah dengan nomor unit angka arab

1. Pustaka dakam naskah difulis dalam -sistem nama-tahun. Bita pustaka mempunyai lebih dan dua penulis dilkuti ef al. lalu tahun. Contoh:

Mersunt Thompson (1997), set kanker kehilangan inhibisi kontak.

Gentis Erythring menunjukkan akkivitasnya sebagai inhibitor cyciooxigensse (COX iI) dan anti intlamasi (Pillay ot ai, 2001)

8. Daftar Pustaka disusun dalam urutan abjad secara kronologis :

a. Untuk buku : nama pokok dan inisial pengarang, tahun terbit, judul, itid, edisi, nama penertit. tempat terbit.

b. Untuk karangan dalam buku s nama pokok dan inisial pengarang. tahun, judul karangan, inisial dan rama editor : judial buku, halaman permulaan dan akhir (karangan), nama penertit, tempat terbit.

c. Untuk karangan dalam majalah atai jurnat : nama pokok dan inisial pengarang. lahun, joduh karangan, singkatan nama majalah (ditulis italic), volume momor (ditulis diabic), halaman permulaan dan aktir karangan tersebut.

Contoh:

Ansel, H.C. 1989, Pengantar Bentisk Sediaan Fammasi, diteriemahikan oleh tbrahim. F, edisi NV, Ut Press. Jakarta pp. 124-134

Grudee, 1. 1986, The influence of Systemic and Local Factors on the Development of Atherosilerosis, dalam J.K. Maruki and S. Bagio (eds) ; Human Alherosclerosis, pp. 131-164. Academi Press, London. 


\title{
UJI EFEK HEPATOPROTEKTIF INFUS HERBA PEGAGAN (Centella asiatica, (L.) Urb) PADA TIKUS PUTIH GALUR WISTAR YANG TERINDUKSI PARASETAMOL
}

\author{
Islamiyah Neda Rahayu, Farida Hayati \\ Prodi Farmasi Universitas Islam indonesia
}

\begin{abstract}
Acetaminophen is a kind of analgetic-antipyretic drug which the usage in excessive dose will cause the liver damage. Pegagan herb (Centella asiatica, L) is one of plant which is used to protect the fiver from various damage of drug. A research to study the hepatoprotective effect of pegagan herb infusion on acetaminophen induced wistar rat has been conducted. This research was aimed to find how excellent pegagan herb protects the liver from the damages caused by acetaminophen and find the data of hepatoprotective of pegagan herb's dose effect span in infussion form through the SGPT enzym and hyspatology of liver cell analysis. This research used the completed random of unidirectoral pattem method, using wistar strain white rat as the tested animals, weight $200 \mathrm{~g}=10 \%$, age $5-8$ weeks. The way of attemp: 38 rat were divided into 6 groups were each groups had 6 rat. For the treatment. Group I was controlled by aquadest. Group II was given acetaminophen suspension dose $2,5 \mathrm{~g} / \mathrm{kg}$ BB. Group III-IV was given pegagan herb infussion 0,$027 ; 0,054 ; 0,0108 ; 0,216 \mathrm{~g} / \mathrm{kg}$ BB once in $\mathrm{a}$ day for a week and 8 hours after that, on the seventh day was given acetaminophen suspention dose $2,5 \mathrm{~g} / \mathrm{kg}$ BB. Blood taking was conducted by orbitalis sinus before th treatment, 8 hours after the seventh day treatment and 24 hours after acetaminophen was given. SGPT data was analysed by ANOVA statistical test, where if found the significant difference, it would continue by Tuckey Test with $95 \%$ as significant standar continued by hyspatology test on liver cell of rat. The result of this research showed that pegagan herb infussion dose 0,$027 ; 0,054 ; 0,108 ; 0,216 \mathrm{~g} / \mathrm{kg}$ BB had a hepatoprotoctive effect on acetaminophen inducted white rat successively $34,19 \% ; 62,52 \%$; $78,62 \% ; 85,69 \%$. And the result of qualitative analysis by histology analysis showed that pegagan herb had hepatoprotective effect.
\end{abstract}

Keyword: Hepatoprotective, Pegagan Herb,Acetaminophen

\section{PENDAHULUAN}

Hati merupakan organ terbesar dalam tubuh manusia. Di dalam hati terjadi proses-proses penting bagi kehidupan, di antaranya pengaturan metabolisme (Anonim,2004b), baik untuk metabolisme zat makanan juga sebsgian besar obat dan toksikan. Sebagian toksikan memasuki tubuh melalui sistem gastrointestinal, dan setelah diserap, toksikan dibawa oleh vena porta ke hati $(\mathrm{Lu}, 1995)$.

Parasetamol sebagai derivat asetanilid merupakan metabolit fenasetin dengan efek analgetik dan antipiretik aman digunakan, tetapi bukan berarti tidak berbahaya. Keracunan serius bisa terjadi dengan sedikitnya 12-20 tablet parasetamol @ $500 \mathrm{mg}$ sekall telan. tergantung kapasitas individual setiap orang. Waktu paruh parasetamol dalam darah $2-4$ jam, sehingga dapat dipakai sebagai ukuran untuk menilai derajat keseriusan keracunan (Darmansjah, 2004). 
Transaminase merupakan sekelompok enzim. Enzim yang sering digunakan untuk menilai penyakit hati adalah GPT (Glutamat Piruvat Transaminase) karena merupakan indikator yang peka terhadap kerusakan sel-sel hati. Enzim ini sebagian besar terikat dalam sitoplasma hati. Bila terjadi kerusakan pada membran sel hati oleh suatu sebab misalnya alkohol, obat-obatan, infeksi virus dan sebagainya, maka enzim GPT akan terlepas dan masuk ke dalam peredaran darah sehingga kadarnya di dalam serum meningkat (Duncan đan Carlyle, 1983).

Kini, selain pengobatan medis kadokteran, tidak sedikit dokter yang menyarankan pengobatan herbal (Anonim, 2004a). Salah satu tanaman obat yang dikenal luas di selunih dunia sebagai obat dan sangat aman digunakan adalah pegagan (Centella asiatica L (Urban)), Sejalan dengan mekanisme kerja pegagan pada tubuh, tumbuhan ini juga terbukti secara klinik mampu mengobati luka bakar, sirosis hati, keloid scleroderma, dan gangguan pembuluh vena, mengatasí kepikunan dan meningkatkan kecerdasan (Handra, 2004). Zat pahit dan zat samak, bersifat melindungi set hat dari berbagai kerusakan akibat racun maupun zat berbahaya, maka dapat juga untuk mengobati liver, radang hati, dan pembengkakan hati (Manan, 2003).

Untuk mengatasi masalah kerusakan hati, diupayakan penelitian untuk mendapatkan alternatif obat baru yang berkhasiat untuk mencegah maupun mengobati, yaitu dengan mencari obat-obat dari alam yang lelah digunakan secara tradisional. Salah saturya yaitu tanaman obat herba pegagan. Diharapkan hasil dari peneitian ini akan memperkaya daftar tanaman obat yang berkhasiat sebagai hepaloprotektif.

Penelitian oleh David (2004) telah membuktikan adanya efek hepatoprotektif ekstrak etanol herba pegagan (Centella asiatica (L.) Urban) pada mencit jantan terinduksi parasetamol. Penegasan kembali penelitian ini menggunakan infus herba pegagan, dikarenakan penggunaan pengobatan pada masyarakat yang secara tradisional lebih mudah pembuatannya dalam bentuk infusa dari pada pembuatan dalam bentuk ekstrak etanol.

\section{METODE PENEUTIAN}

\section{Bahan Penelitian}

Subjek uji tikus putih (Raftus norvegicus) galur wistar, bobot 200 gram $\pm 10 \%$, umur 5-8 minggu. Bahan simplisia herba pegagan, paracetamol. Na-CMC, aqua destillata, alkohol, formalin, zat wama hematoksilin-eosin.

\section{Alat Penelitian}

Alat jarum tuberculin, spuit oral volume $2.5 \mathrm{mi}$, sentrifuge, vortex, seperangkat alat bedah, mikrotom, mikroskog dan kamera. 


\section{Jalannya Penelitian}

1. Koleksi dan determinasi tanaman herba pegagan.

2. Penentuan dosis infus herba pegagan. Dosis herba pegagan kering $0,6 \mathrm{~g}$ (Anonim, 1998). Dusis untuk tikus : $0,018 \times 0,6 \mathrm{~g}=0,0108 \mathrm{~g} / 200 \mathrm{~g}=0,054 \mathrm{~g} / \mathrm{kg}$ BB. Varlasi dosis yang digunakan dalam penelitian ini adalah infus herba pegagan: $0,027 \mathrm{~g} / \mathrm{kg}$ BB; $0,054 \mathrm{~g} / \mathrm{kg}$ BB; $0,108 \mathrm{~g} / \mathrm{kg} \mathrm{BB} ; 0,216 \mathrm{~g} / \mathrm{kg} \mathrm{BB}$. Dosis ditentukan berdasarkan orientasi dan mengacu pada dosis pernakaien manusia.

3. Pembuatan Infusa herba pegagan, $2,7 \mathrm{~g}$ simplisia dicampur dengan air $90^{\circ} \mathrm{C}$ selama 15 menit dałam panci infusa, sambil diaduk, Serkai setagi panas, tambahkan air panas secukupnya hingga volume $100 \mathrm{~mL}$. (Anonim, $1995 \mathrm{~b}$ ).

4. Pembuatan tantan CMC1\% untuk mensuspensikan Parasetamol (1g CMC larutkan dalam air panas $100,0 \mathrm{mi}$ ).

5. Penentuan dosis parasetamol. Dosis- parasetamol dipilih berdasarkan dosis hepatotoksiknya terhadap tikus putih yaitu: $2,5 \mathrm{~g} / \mathrm{kg}$ BB (Donatus 1995).

6. Pembuatan suspensi parasetamol (konsentrasi $0,5 \mathrm{gram} / 2 \mathrm{ml}$ dalam CMC 1\%).

7. Penetapan tolok ukur kerusakan sel hati

Metode rancangan acak lengkap pola satu arah dengan 36 ekor tikus dibagi dalam 6 kelompok, masing-masing kelompok 6 ekor tikus, Kelompok t: kontrol aquades (p.o). Kelompok II : Kontrol negatf (parasetamol $2,5 \mathrm{~g} / \mathrm{kg} \mathrm{B8}$ ). Kelompok III-VI berturut-turut diberi perlakuan infusa pegagan (p.o) dosis $0,027 \mathrm{~g} / \mathrm{kg}$ B8; 0,054 g/kg BB; 0,108 g/ kg BB; $0,216 \mathrm{~g} / \mathrm{kg}$ BB dosis tunggal selama 6 hari, 8 jam setelah hari ke-6 diambil darahnya dan diberi parasetamol dosis toksik $2.5 \mathrm{mg} / \mathrm{kg}$ BB. 48 jam kemudian diambil darah hewan uj guna menentukan aktifitas enzim serum. Hewan uji dikorbankan untuk dibuat preparat histopatologi,

8. Pengambilan serum.

Tikus dipuasakan selama $16-18$ jam, diambil darahnya $1,5 \mathrm{ml}$ melalui sinus orbitafis.

Diinkubasi pada suhu kamar (15 menit), disentrifuse dengan kecepatan $3500 \mathrm{~mm}$ (10 menit), iambil bagian serum.

9. Analisis aktifitas SGPT (Deutsche gesselchraft fur klinische chemie (Modified IFCC (U.V. Kinetic))

Untuk analisis fotometri aktifitas enzim SGPT, dilakukan serangkaian reaksi berikut : Serum $(100 \mu)$ ditambah larutan reagen R1 $(1000 \mu$ ), diamkan selama 5 menit, tambahkan larutan reagen $R 2$ (250 $\mu 1)$ campur dan baca resapan datam 1 menit pada $\lambda .340 \mathrm{~nm}$ (37" C) hasil yang diperoleh dikalikan dengan factor 1746. SGPT dinyatakan dalam U / L (Anonim f. 2004).

10. Pemeriksaan histologis sel-sel hati dilakukan di Laboratorium Patologi dan Anatomi Fakultas Kedokteran Hewan Universitas Gajah Mada Yogyakarta. 


\section{Analisis dan evaluasi hasil}

Analisis kuantitatif berdasarkan data aktivitas enzim SGPT. Daya hepatoprotektif dihitung dengan persamaan sebagai berikut:

Daya hepatoprotektif $=\frac{A G P T p s t-A G P T d}{A G P T p s t-A G P T k t r} \times 100 \%($ Sulistyawati, 2002).

Dimana AGPT pst: rata-rata aiktifitas SGPT kontrol parasetamol $(2,5 \mathrm{~g} / \mathrm{kg}$ BB); AGPT ktr (kontrol) : rata-rata aktifitas SGPT aquadest; AGPTd: rata-rata aktifitas SGPT dosis uji setelah 48 jam. Aralisis statistik menggunakan anava pola searah dan diteruskan uji tukey tara! kepercayaan $95 \%$. Data hasil pemeriksaan histopatologi dianalisis secara kualitati.

\section{HASIL DAN PEMBAHASAN}

\section{A. Penetapan Aktivitas Enzim GPT serum}

Pemeniksaan GPT-serum menggunakan metode IFCC (Intemasional Federation of Clinical Chemistry (modit), dilakukan di Laboratorium Patologi Klinik Fakultas Kedokteran Hewan, Universitas Gajah Mada.

Penentuan waktu kehepatotoksïkan parasetamol mencapai maksimum bertujuan untuk mengetahui waiktu di mana parasetamol dosis 2,5 g/kg BB menyebabkan derajat kerusakan hati yang tertinggi, ditunjukkan dengan kenaikan aktivitas GPT-serum yang maksimal dan terjadinya nekrosis hati pada gambaran histopatologi hat. Peneiitian Yuningsih (2003) membuktikan adanya kenaikan SGPT pada jam ke-48 setelah pemberian perasetamol dosis $2,5 \mathrm{~g} / \mathrm{kg} \mathrm{BB}$.

\section{B. Hasil aiktivitas GPT-serum}

Tabei L. Data aktivitas GPT-serum tikus 8 jam sebelum pemberian parasetamol dosis 2,5 g/kg BB

\begin{tabular}{|c|c|c|c|c|c|c|}
\hline \multirow[b]{2}{*}{ No } & \multicolumn{6}{|c|}{ Aktivitas GPT-serum (U/L) } \\
\hline & $\begin{array}{l}\text { Kontrol } \\
\text { Aquadest }\end{array}$ & $\begin{array}{c}\text { Kontrol } \\
\text { Parasetamof }\end{array}$ & $\begin{array}{c}\text { Pegagan } \\
0,027 \text { g/kg } \\
\text { B8 + } \\
\text { Parasetnmol }\end{array}$ & $\begin{array}{c}\text { Pegagan } \\
0,054 \mathrm{~g} / \mathrm{kg} \mathrm{BB} \\
+ \\
\text { Parasetamol }\end{array}$ & $\begin{array}{c}\text { Pegagan } \\
0,108 \mathrm{~g} / \mathrm{kgBB} \\
+ \\
\text { Parasetamol }\end{array}$ & $\begin{array}{c}\text { Pegagan } \\
0,216 \mathrm{~g} / \mathrm{kg} \\
\text { BB + } \\
\text { Parasotamol }\end{array}$ \\
\hline 1 & 13,23 & 13,23 & 6,65 & 6.65 & 6.65 & 13,23 \\
\hline 2 & 6,65 & 13,23 & 6.65 & 6,65 & 6.65 & 5,65 \\
\hline 3 & 6.65 & 6.65 & 6.05 & 6.65 & 6.65 & 6,65 \\
\hline 4 & 6,65 & 13,23 & 6,65 & 13,23 & 6,65 & 13,23 \\
\hline 5 & 6,65 & 19,05 & 13,23 & 6.65 & 13,23 & 13,23 \\
\hline 6 & 1323 & 6.65 & 6.65 & 13.23 & 18.85 & 13,23 \\
\hline$X \geq S E$ & $8,84 \geq 3,39$ & $12,14 \div 4,96$ & $7,74+2,68$ & $8,84 \pm 3,39$ & $9,94+5,51$ & $11,03+9,75$ \\
\hline
\end{tabular}

Hasil analisis aktivitas GPT-serum 8 jam sebelum pemberian parasetamol dosis foksik $\{2,5$ gikg BB) menunjukkan nilai yang hampir sama. Hassil analisis uji Tukey menunjukkan perbedaan yang tidak bermakna $(p>0,05)$. 
Tabel II. Data aktivitas GPT-serum tikus terinduksi parasetamol setelah praperlakuan infus herba pegagan.

\begin{tabular}{|c|c|c|c|c|c|c|}
\hline \multirow[b]{2}{*}{ No } & \multicolumn{6}{|c|}{ Aktivitas GPT-serum (U/L) } \\
\hline & $\begin{array}{l}\text { Kontrol } \\
\text { Aquadest }\end{array}$ & $\begin{array}{c}\text { Kontrol } \\
\text { Parasetamol }\end{array}$ & $\begin{array}{l}\text { Pegagan } \\
0,027 \text { g/kg } \\
88+\text { Pct }\end{array}$ & $\begin{array}{c}\text { Pegagan } \\
0,054 \mathrm{~g} / \mathrm{kg} \\
\mathrm{BB}+\mathrm{Pct}\end{array}$ & $\begin{array}{c}\text { Pegagan } \\
0,108 \mathrm{~g} / \mathrm{kg} \\
\mathrm{BB}+\mathrm{Pct}\end{array}$ & $\begin{array}{c}\text { Pegagan } \\
0,216 \text { g/kg } \\
\text { B日 + Pct }\end{array}$ \\
\hline 1 & 13,23 & 79.69 & 6905 & 42.76 & 29.80 & 13.23 \\
\hline 2 & 6.65 & 92,94 & 46,65 & 40.00 & 26.47 & 23.23 \\
\hline 3 & 6,65 & 89,71 & 72,80 & 33.85 & 23,23 & 19,85 \\
\hline 4 & 6.65 & 86,05 & 54,32 & 33.85 & 23,23 & 23,23 \\
\hline 5 & 13,23 & 89,71 & 68,65 & 39.85 & 29,80 & 19.85 \\
\hline 6 & 6.65 & 79,42 & 46,65 & 42,76 & 19.85 & 16.67 \\
\hline X:SE: & $8,84 \pm 1,38$ & $86,25 \div 2,29$ & $59,78 \div 4,89$ & $37,85+1,83$ & $25,39 \pm 1,63$ & $19,91 \pm 1,19$ \\
\hline
\end{tabular}

Smith (1988) menyebutkan bahwa nilai normal dari Alanin Transaminase (SGPT) tikus adalah tidak lebih dari 30,2 (U/L). Nilai GPT-serum untuk hepatoprotektif yang baik berkisar antara $20 \%$ sampai $80 \%$.

Terlihat aktivitas GPT-serum tikus yang ditheri senyawa hepatotoksin parasetamol dosis 2,5 g/kg BB, yaitu $86,25 \pm 2,29$ U/L Berbeda dengan keadaan tersebut, kelompok $t$ kontrol aquades aktivitas GPT-serumnya lauh lebih kecil, yaitu $8,84 \pm 1,38$ U/L. Hepatotoksin ini menunjukkan kondisi paling buruk dengan nilai akdivitas enzim GPT-senum tertinggi tanpa prapertakuan dengan infus herba pegagan.

Tabel III. Pengaruh perlakuan infus herba pegagan selama 6 hari terhadap kehepatotoksikan parasetamol dosis $2,5 \mathrm{~g} / \mathrm{kg}$ BB (48 jam setelah pemberian parasetamol).

\begin{tabular}{|c|c|c|c|c|c|}
\hline \multirow{3}{*}{ Kelompok. } & \multirow{3}{*}{ Perlakuan } & \multirow{3}{*}{$\mathrm{n}$} & \multicolumn{3}{|c|}{ Kehepatotoksikan Parasetamol } \\
\hline & & & \multirow{2}{*}{$\begin{array}{c}\text { Mean }+5 E \\
\text { (UIL) }\end{array}$} & \multicolumn{2}{|c|}{ \% beda terhadap } \\
\hline & & & & $\begin{array}{c}\text { Kontrol } \\
\text { Aquadest }\end{array}$ & $\begin{array}{c}\text { Kontrol } \\
\text { parasutamol }\end{array}$ \\
\hline$T$ & Kontrol Aquadest & 6 & $8,84 \pm 1,38$ & - & $(-189,75 \%$ \\
\hline II & Parasetamol & 6 . & $86,25 \pm 2,29$ & $(+) 875,67 \%$ & $*$ \\
\hline III & $\begin{array}{l}\text { Pegagant- } \\
D=0,027+P\end{array}$ & 6 & $59,78 \pm 4,89$ & $(+) 576,24 \%^{*}$ & $(-) 30,68 \%$ \\
\hline IV & $\begin{array}{l}\text { Pegagan- } \\
D=0,054 \text { *P }\end{array}$ & 6 & $37,85 \pm 1,83$ & $1+1328,16 \%^{\circ}$ & $\left(-956,11 \%^{6}\right.$ \\
\hline$v$ & $\begin{array}{l}\text { Pegagan- } \\
D=0,10 B+P\end{array}$ & 6 & $25,39 \pm 1,63$ & $(+) 187,21 \%$ & $(-1) 70,56 *^{6}$ \\
\hline VI & $\begin{array}{l}\text { Pegagan- } \\
D=0,216+P\end{array}$ & 6 & $19.91 \pm 1.19$ & $(+) 125,22 \%$ & $(-9) 76.91 \%$ \\
\hline
\end{tabular}




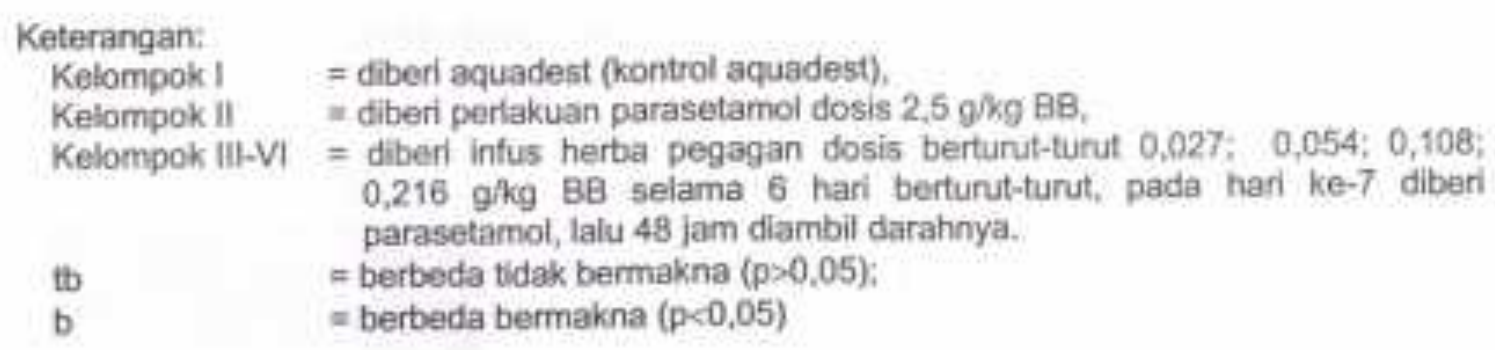

Secara statistika kenaikan nitai enzim GPT-serum kontrol parasetamol (kelompok II) menunjukkan perbedaan bermakna $(\mathrm{p}<0.05)$ Berdasarkan analisis statistika Anava pola satu arah dan uji homogenitas varian diketahui bahwa aktivitas enzim GPT-serum pada keseluruhan kelompok pada kondisi normal, menunjukcan perbedaan yang bermakna $(p<0,05)$.

Tabel IV. Daya hepatoprotektif infus herba pegagan pada tikus terinduksi parasetamol

\begin{tabular}{|c|c|}
\hline Dosis $(g / \mathrm{kg} \mathrm{BB})$ & Daya hepatoprotektif $(\%) \pm \mathrm{SD}$ \\
\hline 0,027 & $34,19 \% \neq 12,00$ \\
0,054 & $62,52 \% \pm 4,49$ \\
0,108 & $78,62 \% \pm 4,00$ \\
0,216 & $85,69 \% \pm 2,93$ \\
\hline
\end{tabular}

Keterangan : Daya hepatoprotektif dihitung berdasarkan rumus :

AGPT PSt-AGPTD $\times 100 \%$

AGPT Pst - AGPTKt

Untuk dosis 0,027 g/kg B8 (kelompok III) aitivitas GPT-serumnya lebih tinggi dibandingkan dengan ke-3 dosis infus herba pegagan yang lain sedangkan pada infus herba pegagan dosis $0,216 \mathrm{~g} / \mathrm{kg}$ BB aktivitas GPT-serum lebih kecil hal ini kemungkinan disebabkan oleh jumlah antioksidan optimal sehingga aktivitas GPT-serum lebih kecil dibandingkan dosis lain.

\section{Hasil pemeriksaan histologi sel-sel hati tikus.}

Analisis histologi sel-sel hati dilakukan untuk mengetahui keadaan mikroskopi sel hati setelah pemberian hepatotoksin (parasetamol) dan pengaruh perlakuan dengan infus herba pegagan. Dari hasil analisis histologi sel-sel hat nampak bahwa prapertakuan infus herba pegagan mampu menurunkan tingkat nekrosis sel hati sesuai dengan kenaikan dosis. Nekrosis sel hati akibat hepatotoksin bersifat zonal karena kerusakan ferjadi pada sebagian sel-sel hati 
Tabel V. Hasil pengamatan mikroskopis sel hati tikus yang diberi praperlakuan infus herba pegagan.

\begin{tabular}{|c|c|c|}
\hline KELOMPOK & PERUBAHAN YANG TERJADI & KELOMPOK \\
\hline Kontrol aquadest & $\begin{array}{l}\text { Tidak ada perubahan, Sel hati tampak } \\
\text { normal, hepatosit tampak baik. Tampak } \\
\text { sel hati yang tersusun dari lobulus yang } \\
\text { letaknya tersusun radier. Terdapat } \\
\text { sedikit infiltrasi mononuklear di daerah } \\
\text { periportal. }\end{array}$ & $\begin{array}{l}\text { Keterangan: a, Vena sentralis } \\
\text { b. Inti sel c. sinusoid }\end{array}$ \\
\hline $\begin{array}{l}\text { Parasetamol } \\
\text { dosis2.5 g/kg BB }\end{array}$ & $\begin{array}{l}\text { Nekrosis sentrolobular fipe zona }+3 \text {. } \\
\text { lerjadi pernbengkakan hepatosit disertai } \\
\text { penyempitan sinusoid, infiltrasi sel } \\
\text { mononuclear di jaringan interiobular } \\
\text { lerutama di daerah peiportal. Hepatosit } \\
\text { tidak tersusun radier. Di daerah } \\
\text { perportal terdapat nekrosis disertai } \\
\text { hemoragi }\end{array}$ & $\begin{array}{l}\text { Keterangan: a. Vena sentratis } \\
\text { b. Nekrosis sentrolobular }\end{array}$ \\
\hline $\begin{array}{l}\text { Infus herba } \\
\text { pegagan dosis } \\
0,027 \text { g/kg BB } \\
+ \text { Parasetamol }\end{array}$ & $\begin{array}{l}\text { Nekrosis sentrolobular fipe zonal }+2 \text {. } \\
\text { Disertai infiltrasi sel mononuclear, } \\
\text { pembengkakan hepatosit. }\end{array}$ & \\
\hline & & $\begin{array}{c}\text { Keterangan: a. Vena sentralis } \\
\text { b. Nekrosis sentrolobular }\end{array}$ \\
\hline $\begin{array}{c}\text { Infus herba } \\
\text { pegagan dosis } \\
0,216 \mathrm{~g} / \mathrm{kg} \text { BB } \\
+ \text { Parasetamolinfus } \\
\text { herba pegagan } \\
\text { dosis } 0,054 \mathrm{~g} / \mathrm{kg} \\
\text { BB +Parasetamol }\end{array}$ & $\begin{array}{l}\text { Nekrosis sentrolobular tipe zonal }+2 \\
\text { Terdapat infiltrasi mononuclear }\end{array}$ & $\begin{array}{l}\text { Keterangan: a. Vena sentralis } \\
\text { b. Nekrosis sentrolobular }\end{array}$ \\
\hline $\begin{array}{c}\text { Infus herba } \\
\text { pegagan dosis } \\
0,108 \mathrm{~g} / \mathrm{kg} \mathrm{BB} \\
+ \text { Parasetamol }\end{array}$ & $\begin{array}{l}\text { Nekrosis sentrolobular tipe zonal }+1 \\
\text { Infiltrasi mononucklear di periportal, } \\
\text { terdapat focal nekrosis diperifer }\end{array}$ & $\begin{array}{l}\text { Keterangan: a. Vena sentralis } \\
\text { b. Periportal c.Nekrosis } \\
\text { sentrolobular }\end{array}$ \\
\hline $\begin{array}{c}\text { Infus herba } \\
\text { pegagan dosis } \\
0.216 \mathrm{~g} / \mathrm{kg} \mathrm{BB} \\
+ \text { Parasetamol }\end{array}$ & $\begin{array}{l}\text { Nekrosis sentrolobular tipe zonal }+1 \\
\text { Infiltrasi ringan mononuclear di } \\
\text { periportal }\end{array}$ & $\begin{array}{l}\text { Feterangan: a. Vena sentratis } \\
\text { b. Inti sel c. Sinusoid. }\end{array}$ \\
\hline 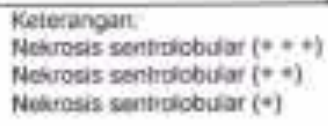 & $\begin{array}{l}=60 \% 5 \times 560 \% \\
=30 \% 5 \times 360 \% \\
=10 \%<x=30 \% .\end{array}$ & \\
\hline
\end{tabular}


Pada keadaan normal (dosis terapi) parasetamol dimetabolisme dan membentuk konjugasi dengan asam sulfat dan glukoronida dan sisanya dimetabolisme menjadi metabolit toksik yang didetoksifikasi dengan cara konjugasi dengan glutation. Jika jumlah glutation berkurang atau jumlah parasetamol berlebih maka metabolit toksik akan berikatan dengan makromolekoul sel hati dan menyebabkan nekrosis sentrolobular dengan sedikit degenerasi melemak dan peradangan dan ditandai secara biokimiawi dengan naiknya aktivitas enzim GPT-senm, karena permeabilitas membran sel berubah sehingga enzim dan sitosol bocor dan masuk ke aliran darah. Nekrosis sel hati pada daerah sentrolobular terjadi karena sitokrom P.450 dihasilikan oleh organella sitosom yang terdapat di daerah sentrolobutar, selain itu pada daerah sentrolobular juga menerima sisa metabolisme dari daerah midzonal dan periportal.

\section{Evaluasi Efok hepatoprotektif}

Peranan infus herba pegagan sebagai agen hepatoprotektif terhadap kehepatotoksikan parasetamol kemungkinan melalul penangkapan senyawa berstruktur elektrofil yang merupakan bentuk metabolit toksik parasetamol. Herba pegagan mengandung zat pahit dan zat samak, yang bersifat melindungi sel hati dari berbagai kerusakan akibat racun maupun zat berbahaya (Manan, 2003), maka dapat diduga herba pegagan dapat digunakan untuk mengobati liver, radang hati, dan pernbengkakan hati. Walaupun demikian senyawa aktif yang bertanggung jawab sebagai agen hepatoprotektif belum dapat dipastikan.

\section{KESIMPULAN}

1. Infus herba pegagan dosis 0,$027 ; 0,054 ; 0,108$ dan $0,216 \mathrm{~g} / \mathrm{kg}$ B日 dapat memberikan efek hepatoprotektif pada tikus putih yang terangsang parasetamol.

2. Daya hepatoprotektif infus herba pegagan dosis 0,$027 ; 0,054 ; 0,108$ dan $0,216 \mathrm{~g} / \mathrm{kg}$ B8 berturut-turut sebesar $34,19 \% ; 62,52 \% ; 78,62 \% ; 85,69 \%$

3. Hasil analisis histologi sel hati, diketahui bahwa dengan kenaikan dosis teriadi penurunan tingkat kerusakan sel hati tikus,

\section{DAFTAR PUSTAKA}

Anonim, 1995 b, Ilmu Resep Teori Untuk Sekolah Menengah Famasi, Jilid It, Departemen Kesehatan Pusat Pendidikan Tenaga Kesehatan, Surabaya, 82-3.

Anonim, 1998. PDR for Herbal Medicines, Edisi I, Medical Economics Company, Montvale, New Jersey, $729-30$.

Anonim, 2004 a, Aneka Ramuan Pengusir Kanker, 28 Juni 2004, http:l/www. pikiranrakyat.comicatak/0704/01/cakrawalallainnya 03. htm, (Diakses 16 Desember 2004). 
Anonim, 2004 f. Pegagan (Centella asiatica, Urban) hitto://umw. asiamaya.com/iamu/isi/pegagan centellaasiatica htm. (Diakses 14 Oktober 2004).

Backer, C.A, and Van den Brink, R.C., 1965, Flora of Java, Volume Il, N.V.P, Nordhoff, Groninger, Netherland, 171, 173.

Darmansjah, 1. 2004, Parasetamol dan nekrosis hat,. Medical article, hitp: /imww imandarmansiah.web.id/ (Diakses 10 Desember).

Donatus, I.A., 1995, Hati, Dalam Suryawati, S., (Eds.) Efek Samping Obat, Edisi 2, Pusat Studi Farmakologi Klinik dan Kebijakan Obat Universitas Gajah Mada, 85-98.

Duncan, H. R., and Cartyle, J. T., 1983, Veterinary Pathology, $5^{\text {th }}$ edition. Lea and Febiger, Philadelphia. Pp, 851-853.

Handra. H, 2004, Pegagan, Tumbuhan Tertupakan Kaya Manfaat Antr-"cellulite" http://uww kompas.com/Kompas catak/0404/02/ilpeno/948005.hitm (Diakses 16 Desember 2004).

Lu, F.C. 1995, Toksikologi Dasar, Asas, Organ Sasaran dan Penilaian Resiko, terjemahan Edi Nugroho, Edisi ke II, 206-8, Penerbit Universitas indonesia, Jakarta.

Manan, 2003, pegagan, Obat Lepra dan Ginjal, http://mww. suaramerdeka.com/ragam/html.at hitp://uww gooole.com, (diakses 31 Desember 2004).

Smith., J.8. dan Mangkowidjojo, S., 1988, Perneliharaan, Pembiakan dan Penggunaan Hewan Percobaan di Daerah Tropis, Ui Press, Jakarta, 38-45

Sulistyawati, R, 2002, Efek Hepatoprotektif Ekstrak Etanoi (Kaempferia rotunda, L) pada tikus jantan galur wistar terangsang paracetamol, Sknipsi, Fakultas Farmasi, Universitas Gajah Mada, Jogjakarta.

Yuningsih, Y., 2003, Ujl efek hepatoprotektif infus daun teh (Cameliia sinensis, (L).O.K) pada tikus jantan terangsang parasetamol, Skripsi, Fakultas Farmasi Universitas Sanata Dharma, Jogjakarta. 